\title{
Celebrating 10 years of publishing Bioanalysis
}

\author{
Laura Dormer*,1 \\ ${ }^{1}$ Future Science Group, Unitec House, 2 Albert Place, London, N3 1QB, UK \\ *Author for correspondence: I.dormer@future-science-group.com
}

\section{"There have been many changes in the publishing landscape since the journal first began, and it is} satisfying to see how the journal has evolved during that time"

First draft submitted: 27 February 2019; Accepted for publication: 1 March 2019; Published online:

4 April 2019

Keywords: bioanalysis $\bullet$ publication

It has been a great pleasure to watch the development of Bioanalysis from its launch in 2009 to its current place as a leading journal in the field of regulated quantitative bioanalysis. There have been many changes in the publishing landscape since the journal first began, and it is satisfying to see how the journal has evolved during that time, currently under the excellent guidance of Managing Editor Sankeetha Nadarajah. In this brief article, I will look back over developments at the journal, and in the wider publishing industry, over the past decade.

\section{Editorial leadership}

In spring 2008, launch work on Bioanalysis began in earnest, under the guiding hand of Launch Editor Ryan De Vooght-Johnson. One of the crucial steps in the launch of a new journal is establishing a strong Editorial Board, and we were pleased to welcome Senior Editors Dr Brian P Booth (Deputy Director, Division of Clinical Pharmacology V, Office of Clinical Pharmacology, US FDA, MD, USA) and Dr Howard Hill (then Global Director of Analytical Chemistry at Huntingdon Life Sciences, UK), along with a strong team of Associate Editors representing expertise in key topics in the field, and an extensive international Editorial Board.

We were delighted to work with both Brian and Howard in establishing the journal in its early years. In 2013, Howard stepped down from the role and was replaced by Editorial Board member Neil Spooner - then Director, Bioanalytical Science \& Toxicokinetics, at GSK (UK). Following Brian's departure from the role in 2015, Neil has headed up the Editorial Board (as well as founding Spooner Bioanalytical Solutions in 2016, of which he is Founder and Director) and has been a superb guide, sounding board and support for the journal's editorial team.

\section{Journal milestones}

Such was the enthusiasm for the topic when the journal first appeared, we were able to launch as a monthly journal - a great testament to the passion in the field and the high quality of the content we were receiving. The journal quickly rose to its current, twice-monthly publication schedule, which has been in place since 2011. Our approach for including a mixture of content has proved successful across our portfolio, and nowhere more so than in Bioanalysis - mixing high-quality commissioned content with unsolicited article submissions, and a mixture of original research, opinion pieces, white papers and more.

Often a challenging step in establishing a new journal is securing indexing on the major databases - challenging, but crucial to ensure widespread readership of the excellent content being submitted. We were therefore delighted that Bioanalysis was accepted for indexing on Medline and Web of Science in 2010, receiving its first impact factor in 2011.

In recent years the journal has published an annual foreword, highlighting some of the previous year's most read content. This is generally an interesting mirror to developments and hot topics in the field as a whole. Table 1 lists the ten most read articles in Bioanalysis since launch and provides an interesting snapshot of content. Something 
Table 1. Top ten Bioanalysis articles 2009-2019 by readership ${ }^{\dagger}$.

\begin{tabular}{|c|c|c|c|c|c|}
\hline Rank & Article type & Title & Author(s) & Volume(issue) & Ref. \\
\hline 1 & Methodology & $\begin{array}{l}\text { LC-MS/MS-based quantification of kynurenine } \\
\text { metabolites, tryptophan, monoamines and } \\
\text { neopterin in plasma, cerebrospinal fluid and } \\
\text { brain }\end{array}$ & $\begin{array}{l}\text { R Fuertig, A Ceci, SM Camus, E Bezard, AH } \\
\text { Luippold \& B Hengerer }\end{array}$ & $8(18)$ & [2] \\
\hline 2 & Special Feature & $\begin{array}{l}\text { The decennial index of the white papers in } \\
\text { bioanalysis: 'a decade of recommendations } \\
\text { (2007-2016)' }\end{array}$ & W Garofolo \& N Savoie & $9(21)$ & [3] \\
\hline 3 & White Paper & $\begin{array}{l}2017 \text { White Paper on recent issues in bioanalysis: } \\
\text { a global perspective on immunogenicity } \\
\text { guidelines \& biomarker assay performance (Part } \\
3 \text { - LBA: immunogenicity, biomarkers and PK } \\
\text { assays) }\end{array}$ & S Gupta, S Richards, L Amaravadi et al. & $9(24)$ & [4] \\
\hline 4 & White Paper & $\begin{array}{l}2016 \text { White Paper on recent issues in bioanalysis: } \\
\text { focus on biomarker assay validation: (Part } 3 \text { - } \\
\text { LBA: biomarkers and immunogenicity) }\end{array}$ & S Richards, L Amaravadi, R Pillutla et al. & $8(23)$ & [5] \\
\hline 5 & White Paper & $\begin{array}{l}\text { Best practices in performing flow cytometry in a } \\
\text { regulated environment: feedback from } \\
\text { experience within the European Bioanalysis } \\
\text { Forum }\end{array}$ & B van der Strate, R Longdin, M Geerlings et al. & $9(16)$ & [6] \\
\hline 6 & Review & $\begin{array}{l}\text { Validation and verification of measurement } \\
\text { methods in clinical chemistry }\end{array}$ & E Theodorsson & $4(3)$ & [7] \\
\hline 7 & Review & $\begin{array}{l}\text { Parallelism experiments to evaluate matrix } \\
\text { effects, selectivity and sensitivity in } \\
\text { ligand-binding assay method development: pros } \\
\text { and cons }\end{array}$ & J Tu \& P Bennett & $9(14)$ & [8] \\
\hline 8 & White Paper & $\begin{array}{l}2016 \text { White Paper on recent issues in bioanalysis: } \\
\text { focus on biomarker assay validation (Part } 1 \text { - } \\
\text { small molecules, peptides and small molecule } \\
\text { biomarkers by LCMS) }\end{array}$ & E Yang, J Welink, S Cape et al. & $8(22)$ & [9] \\
\hline 9 & White Paper & $\begin{array}{l}2017 \text { White Paper on recent issues in bioanalysis: } \\
\text { are not BMV guidance/guidelines 'Scientific'? } \\
\text { (Part } 1 \text { - LCMS: small molecules, peptides and } \\
\text { small molecule biomarkers) }\end{array}$ & J Welink, E Yang, N Hughes et al. & $9(22)$ & [10] \\
\hline 10 & Editorial & $\begin{array}{l}\text { The future of microfluidic point-of-care } \\
\text { diagnostic devices }\end{array}$ & FA Gomez & $5(1)$ & [11] \\
\hline
\end{tabular}

that jumps out from this list is the ongoing importance of white papers within the journal; the first such paper was published in the very first issue [1], and these continue to be an important source of guidance and debate.

\section{The publishing landscape}

The publishing landscape has changed a great deal over the past 10 years (in fact, probably almost as much as in the previous 350 years!). Traditionally, journal publishers have had some very important responsibilities, most notably ensuring the quality of the information published, and safely archiving that content so that future work can be built upon it. But with increasing volumes of information being published every day, journal publishers are also now responsible for helping disseminate the research to a broad audience.

Although the use of social media to reach our readership is a more recent development, Bioanalysis has always been at the forefront of using the digital environment to increase the reach of its content. Even from the early years of the journal, the team established an active group on LinkedIn [12], which proved to be a great way to connect with the community and paved the way for the many journal groups we have today. The journal's social media reach was expanded in 2014 when the Twitter group was set up, which now has a growing following of over 1600 [13].

But perhaps most important to the success of Bioanalysis, and as discussed in this issue by my colleague Naamah Maundrell (Senior Editor of Bioanalysis Zone) [14,15], has been our collaboration with sister website Bioanalysis Zone. Launched in 2011, the Zone has provided resources to the bioanalytical community beyond that of the traditional journal publication, including interviews with leading experts in academia and the pharmaceutical industry; informative webinars; and its annual awards in partnership with the journal, recognizing outstanding achievements in the field. 


\section{Conclusion}

There have been many improvements in our publishing services at Bioanalysis since its inception in 2008, and we are still learning and developing. These include the introduction of improved manuscript submission processes (including the launch of our ScholarOne Manuscripts site in 2015 to improve the submission experience); graphical redesigns, including the recent launch of a new cover design; and partnerships with services such as Altmetric [16] and Publons [17] - providing increased information to authors and readers alike on the attention our articles are receiving (Altmetric), and providing recognition to our highly valued peer reviewers (Publons), without whom publication of the journal would be impossible.

I would like to thank all the readers, authors, reviewers and Editorial Board members who have contributed to making the journal such a success since its launch. I look forward to seeing the journal continuing to lead the way in developing and embracing new developments within publishing, and provide a valuable resource for its community, without whom the last 10 years would not have been possible.

\section{Financial \& competing interests disclosure}

L Dormer is an employee of Future Medicine Ltd, part of the Future Science Group. The author has no other relevant affiliations or financial involvement with any organization or entity with a financial interest in or financial conflict with the subject matter or materials discussed in the manuscript apart from those disclosed.

No writing assistance was utilized in the production of this manuscript.

\section{References}

1. Savoie N, Booth BP, Bradley T et al. The 2nd Calibration and Validation Group Workshop on recent issues in Good Laboratory Practice bioanalysis. Bioanalysis 1(1), 19-30 (2009).

2. Fuertig R, Ceci A, Camus SM, Bezard E, Luippold AH, Hengerer B. LC-MS/MS-based quantification of kynurenine metabolites, tryptophan, monoamines and neopterin in plasma, cerebrospinal fluid and brain. Bioanalysis 8(18), 1903-1917 (2016).

3. Garofolo W, Savoie N. The decennial index of the White Papers in bioanalysis: 'a decade of recommendations (2007-2016)'. Bioanalysis 9(21), 1681-1704 (2017).

4. Gupta S, Richards S, Amaravadi L et al. 2017 White Paper on recent issues in bioanalysis: a global perspective on immunogenicity guidelines \& biomarker assay performance (Part 3 - LBA: immunogenicity, biomarkers and PK assays). Bioanalysis 9(24), 1967-1996 (2017).

5. Richards S, Amaravadi L, Pillutla R et al. 2016 White Paper on recent issues in bioanalysis: focus on biomarker assay validation (BAV): (Part 3 - LBA, biomarkers and immunogenicity). Bioanalysis 8(23), 2475-2496 (2016).

6. van der Strate B, Longdin R, Geerlings $\mathrm{M}$ et al. Best practices in performing flow cytometry in a regulated environment: feedback from experience within the European Bioanalysis Forum. Bioanalysis 9(16), 1253-1264 (2017).

7. Theodorsson E. Validation and verification of measurement methods in clinical chemistry. Bioanalysis 4(3), 305-320 (2012).

8. Tu J, Bennett P. Parallelism experiments to evaluate matrix effects, selectivity and sensitivity in ligand-binding assay method development: pros and cons. Bioanalysis 9(14), 1107-1122 (2017).

9. Yang E, Welink J, Cape S et al. 2016 White Paper on recent issues in bioanalysis: focus on biomarker assay validation (BAV) (Part 1 small molecules, peptides and small molecule biomarkers by LCMS). Bioanalysis 8(22), 2363-2378 (2016).

10. Welink J, Yang E, Hughes N et al. 2017 White Paper on recent issues in bioanalysis: aren't BMV guidance/guidelines 'scientific'? (Part 1 - LCMS: small molecules, peptides and small molecule biomarkers). Bioanalysis 9(22), 1807-1825 (2017).

11. Gomez FA. The future of microfluidic point-of-care diagnostic devices. Bioanalysis 5(1), 1-3 (2013).

12. Bioanalysis - the Journal, the Zone LinkedIn group. https://www.linkedin.com/groups/2819540/

13. Bioanalysis Journal Twitter. https://twitter.com/fsgbio

14. Bioanalysis Zone. https://www.bioanalysis-zone.com/

15. Maundrell N. Celebrating the collaboration of Bioanalysis and Bioanalysis zone. Bioanalysis 11(07), 555-556 (2019).

16. Altmetric. https://www.altmetric.com/

17. Publons. https://publons.com/about/home/ 
